\title{
Rapid onset of systemic lupus erythematosus with rarely observed cutaneous lesions
}

\section{Gwałtowny początek tocznia rumieniowatego układowego z rzadko obserwowanymi zmianami skórnymi}

\author{
Martyna Skręta-Śliwińska', Anna Woźniacka', Ilona Kurnatowska²,3, Maciej Goździk²,3, Agnieszka Żebrowska'
}

\author{
'Department of Dermatology and Venereology, Medical University of Lodz, Poland \\ 2Department of Clinical Pharmacology, Ist Department of Internal Medicine, Medical University of Lodz, Poland \\ ${ }^{3}$ Department of Nephrology, N. Barlickiego University Hospital in Lodz, Poland
}

'Klinika Dermatologii i Wenerologii Uniwersytetu Medycznego w Łodzi, Polska

'Zakład Farmakologii Klinicznej I Katedry Chorób Wewnętrznych Uniwersytetu Medycznego w Łodzi, Polska

${ }^{3}$ Oddział Nefrologii Uniwersyteckiego Szpitala Klinicznego im. N. Barlickiego w Łodzi, Polska

\section{CORRESPONDING AUTHOR/ ADRES DO KORESPONDENCJI:} lek. Martyna Skręta-Śliwińska Klinika Dermatologii

i Wenerologii

Uniwersytet Medyczny

w Łodzi

plac Hallera 1 bud. 6

90-647 Łódź

tel.: +48426393093

e-mail: martyna.skreta@gmail.com

\begin{abstract}
Introduction. Systemic lupus erythematosus is a multi-organ connective tissue disease of heterogeneous clinical presentation.

Objective. This article presents a case of a fulminant disease in a woman in which acute cutaneous lesions preceded multi-organ dysfunction, including acute kidney injury.

Case report. Papular eruptions demonstrating a tendency to exudate and formation of erosions appeared on the patient's facial skin. Erosions were present on oral mucosa, and maculopapular lesions developed on thighs. Lesions were accompanied by high fever, general malaise and pain of muscles and joints. Haematological and immunological abnormalities as well as a decrease in kidney function were observed. A rapid development of systemic lupus erythematosus was diagnosed an the treatment with glucocorticosteroids, cyclophosphamide, plasmapheresis and haemodialysis was introduced, resulting in remission.

Conclusions. Acute onset of systemic lupus erythematosus often imitates an infectious disease. Presence of cutaneous lesions typical for systemic lupus erythematosus allows early diagnosis and introduction of appropriate treatment.
\end{abstract}

\section{STRESZCZENIE}

Wprowadzenie. Toczeń rumieniowaty układowy jest wielonarządową chorobą tkanki łącznej o heterogennym obrazie klinicznym.

Cel pracy. Przedstawienie przypadku choroby o piorunującym przebiegu u kobiety, u której zmiany skórne o charakterze ostrym poprzedziły dysfunkcję wielonarządową, $\mathrm{w}$ tym ostre uszkodzenie nerek.

Opis przypadku. U pacjentki na skórze twarzy pojawiły się obrzękowe wykwity grudkowe $\mathrm{z}$ tendencją do wysięku i tworzenia nadżerek. Na błonie śluzowej jamy ustnej obecne były nadżerki, a na udach zmiany o charakterze plamisto-grudkowym. Zmianom towarzyszyła wysoka 
temperatura ciała, ogólne osłabienie oraz bóle mięśni i stawów. Stwierdzono zaburzenia hematologiczne, immunologiczne oraz pogorszenie czynności nerek. Rozpoznano gwałtowny rozwój tocznia rumieniowatego układowego i wdrożono leczenie z zastosowaniem glikokortykosteroidów, cyklofosfamidu, plazmaferez oraz hemodializoterapii, co pozwoliło na uzyskanie remisji choroby.

Wnioski. Toczeń rumieniowaty układowy jest chorobą o ostrym początku, który często imituje chorobę zakaźną. Obecność zmian skórnych charakterystycznych dla tocznia rumieniowatego układowego ułatwia wczesne rozpoznanie choroby oraz wdrożenie właściwego leczenia.

Key words: systemic lupus erythematosus, acute kidney injury, serositis, plasmapheresis.

Słowa kluczowe: toczeń rumieniowaty układowy, ostre uszkodzenie nerek, zapalenie błon surowiczych, plazmafereza.

\section{INTRODUCTION}

Systemic lupus erythematosus (SLE) is a systemic disease manifested with a broad spectrum of clinical and laboratory symptoms, associated with formation of circulatory immune complexes and their deposition in visceral organs and the skin. Women are mostly affected. The diagnosis is most commonly made in patients aged 20-30 years. However autoimmune processes play a crucial role in SLE development, the exact aetiopathogenesis of the disease is not fully understood [1-4].

It is believed that it is a multifactorial disease, developing in genetically predisposed individuals under effect of environmental and hormonal factors, commonly leading to dysfunction of the immune system [5-8].

Some environmental factors stimulating development of the disease are: ultraviolet (UV) radiation, smoking, vitamin D deficiency, medications and exposure to pesticides [9]. UV radiation is the best described and studied trigger of SLE [10]. It is hypothesised that exposure to UV starts apoptosis of keratinocytes, and a defect of phagocytosis leads to accumulation of apoptotic cells in the skin, and to expression of antigens previously "missed" by the immune system. A change in localisation of antigens caused by UV stimulates production of antibodies. Moreover, development of a local inflammation and its secondary necrosis leads to release of inflammatory mediators, resulting in skin injury $[11,12]$.

Numerous clinical trials confirmed that infections may participate in both induction and exacerbation of the pathological process [5-8]. The trial of 2011 conducted on 192 SLE patients demonstrated that all of them, except for one, had a previous contact with the

\section{WPROWADZENIE}

Toczeń rumieniowaty układowy (systemic lupus erythematosus - SLE) jest chorobą układową o różnorodnych objawach klinicznych i odchyleniach w badaniach laboratoryjnych, która wiąże się z tworzeniem kompleksów immunologicznych w krążeniu i ich odkładaniem się w narządach wewnętrznych oraz w skórze. W większości przypadków dotyczy kobiet. Rozpoznanie najczęściej ustala się w wieku 20-30 lat. Zasadniczą rolę w rozwoju SLE odgrywają procesy autoimmunizacyjne, ale dokładna etiopatogeneza nie jest $\mathrm{w}$ pełni poznana [1-4].

Uważa się, że jest to choroba o podłożu wieloczynnikowym, rozwijająca się u osób predysponowanych genetycznie pod wpływem czynników środowiskowych i hormonalnych, które wspólnie prowadzą do zaburzenia funkcjonowania układu immunologicznego [5-8].

Do czynników środowiskowych stymulujących rozwój choroby należą: promieniowanie ultrafioletowe (UV), palenie papierosów, niedobór witaminy D, leki oraz narażenie na pestycydy [9]. Promieniowanie UV jest najlepiej opisanym i zbadanym bodźcem wywołującym SLE [10]. Uważa się, że ekspozycja na promieniowanie UV zapoczątkowuje apoptozę keratynocytów, a defekt fagocytozy przyczynia się do gromadzenia komórek apoptotycznych w skórze i ekspresji wcześniej „niezauważonych” przez układ immunologiczny antygenów. Zmiana lokalizacji antygenów pod wpływem UV stymuluje produkcję przeciwciał. Ponadto rozwój miejscowego stanu zapalnego oraz wtórna do niego nekroza przyczyniają się do uwolnienia mediatorów procesu zapalnego, które prowadzą do uszkodzenia skóry [11, 12].

Liczne badania kliniczne potwierdziły, że infekcje mogą mieć udział zarówno w indukcji, jak i zaostrze- 
EBV virus, which suggest a possible influence of the pathogen. [13] Studies of human endogenous viruses (HERV) also demonstrated that they were important factors triggering numerous autoimmune conditions, including SLE $[14,15]$. Also HTLV-1 and HIV are mentioned in pathogenesis of the disease [16].

The role of genetic factors in SLE has been subject of research after the observation of a more common coexistence of the disease in monozygotic twins $(25 \%)$, compared to dizygotic ones (2\%) [17]. Development of the disease may be also associated with a single gene deficiency, but only in rare cases. Much more commonly there are abnormalities associated with a greater number of genes localised in HLA regions and participating in regulation of the immune system $[8,18,19]$.

Undoubtedly, also sex hormones influence aetiopathogenesis of SLE. It was demonstrated that estrogens and prolactin potentiate the immune response, leading to development of lesions in course of SLE. Also the use of exogeneous estrogens, as a form of contraception or hormonal replacement therapy (HRT) increases the risk of disease in predisposed individuals. Due to their opposite action, androgens have a protective effect. That could explain a great dominance of women among SLE patients [20-22].

\section{OBJECTIVE}

This paper presents a case of a fulminant disease in a 21-y.o. woman in which acute dermatological lesions preceded multi-organ dysfunction, including life-threatening acute kidney injury.

\section{CASE REPORT}

A 21-year old woman was admitted to the Teaching Department of Dermatology and Venreology in Lodz, because of maculopapular rash, erosions of the oral mucosa, significant malaise, fever, dry cough, diarrhoea, vomiting and strong pain of joints and muscles, largely affecting her motor functions, persisting for last 3 weeks. Investigated patient negated any past systemic diseases, use of medication or dietary supplements. First symptoms occurred several days after returning from a skiing trip, during which, besides intense physical exercise, she was highly exposed to sun radiation.

Before admission to the Dermatology ward the woman was an inpatient of the Department of Infectious Diseases, where infectious character of lesions was excluded. Stool tests excluded a possible infection with Clostridium difficile, Campylobacter, Salmonella, Shigella, as well as infections with rotaviruses, adenoviruses or noroviruses. No AH1N1 influenza, HIV, $\mathrm{HBV}$, or HCV infections were found. Importantly, niu procesu chorobowego [5-8]. W badaniu z 2011 roku, w którym brało udział 192 pacjentów ze SLE, wykazano, że wszyscy poza jednym mieli kontakt $\mathrm{z}$ wirusem EBV, co sugeruje wpływ tego patogenu na rozwój choroby [13]. Wyniki badań ludzkich endogennych wirusów (HERV) również wskazały, że są one ważnymi czynnikami wyzwalającymi wiele chorób autoimmunologicznych, w tym SLE [14, 15]. W patogenezie choroby wymienia się także wirusy HTLV-1 oraz HIV [16].

Udział czynników genetycznych w rozwoju SLE stał się przedmiotem badań, gdy zaobserwowano częstsze współwystępowanie choroby u bliźniąt monozygotycznych (25\%) w porównaniu z bliźniętami dizygotycznymi (2\%) [17]. Rozwój choroby może być związany z niedoborem jednego genu, są to jednak rzadkie przypadki. O wiele częściej mamy do czynienia z nieprawidłowościami dotyczącymi większej liczby genów, zlokalizowanych w regionach HLA i biorących udział w regulacji układu immunologicznego $[8,18,19]$.

Niewątpliwy wpływ na etiopatogenezę SLE mają również hormony płciowe. Wykazano, że estrogeny i prolaktyna wzmacniają odpowiedź immunologiczną, co prowadzi do rozwoju zmian w przebiegu SLE. Również stosowanie egzogennych estrogenów jako metody antykoncepcji lub hormonalnej terapii zastępczej (HTZ) zwiększa ryzyko wystąpienia choroby u osób predysponowanych. Androgeny poprzez swoje przeciwne działanie mają charakter ochronny. Wyjaśnia to znaczną przewagę kobiet wśród osób chorujących na SLE [20-22].

\section{CEL PRACY}

Celem pracy jest przedstawienie nietypowego i rzadko występującego przypadku choroby o piorunującym przebiegu u 21-letniej kobiety, u której zmiany skórne o charakterze ostrym poprzedziły dysfunkcję wielonarządową, w tym ostre, zagrażające życiu uszkodzenie nerek.

\section{OPIS PRZYPADKU}

Do Kliniki Dermatologii i Wenerologii w Łodzi została przyjęta 21-letnia kobieta z powodu utrzymujących się od 3 tygodni zmian $\mathrm{w}$ formie osutki plamisto-grudkowej, zmian nadżerkowych na błonie śluzowej jamy ustnej, znacznego ogólnego osłabienia, gorączki, suchego kaszlu, biegunki, wymiotów oraz silnych dolegliwości bólowych stawów i mięśni, które istotnie ograniczały poruszanie. W wywiadzie pacjentka nie podawała przebytych chorób ogólnoustrojowych, dotychczas nie stosowała żadnych leków ani suplementów diety. Pierwsze objawy wystąpiły po kilku dniach od powrotu z wyjazdu na narty, 
C-reactive protein and procalcitonin levels were normal. Blood amylase level was increased to $233 \mathrm{U} / 1$. Also results of liver function tests were increased aspartate aminotransferase (AST) $57 \mathrm{U} / 1$. Levels of lipase $(231 \mathrm{U} / \mathrm{l})$, urea $(151 \mathrm{mg} / \mathrm{dl})$ and creatinine $(161 \mu \mathrm{mol} / 1)$ rose on subsequent days, and estimated glomerular filtration rate (eGFR) decreased to $36 \mathrm{ml} /$ $\min / 1.73 \mathrm{~m}^{2}$. Also leukopenia, anaemia, thrombocytopenia and hypothyroidism (TSH - $5.16 \mathrm{mU} / 1$, fT3 - $2.59 \mathrm{pmol} / \mathrm{l}$, fT4 - $8.85 \mathrm{pmol} / \mathrm{l}$ ) were diagnosed.

Dermatological examination revealed presence of maculopapular lesions demonstrating a tendency to exudate and formation of apical erosions, on the face skin. Numerous erosions were visible on the oral mucosa. They were covered with a grey-yellow, shaggy coating (figs. 1, 2). The vermilion was dry, inflammatory and with numerous erosions. Maculopapular lesions on thighs were significantly less intense (fig. 3).

The physical examination demonstrated blood pressure on the upper limit of normal (RR 140/ $90 \mathrm{~mm} \mathrm{Hg})$, tachycardia (HR $100 \mathrm{bpm}$ ) and fever $\left(38^{\circ} \mathrm{C}\right)$. Vesicular murmur over lung fields was symmetrically absent up to the level of inferior angles of scapulas. No other pathologies were found.

Laboratory investigations completed during two days of hospitalisation demonstrated a gradual intensification of leukopenia (WBC $-2.6 \mathrm{~K} / \mu \mathrm{l})$, anaemia (RBC - $3.34 \mathrm{M} / \mu \mathrm{l}$; HGB - $10 \mathrm{~g} / \mathrm{dl}$; HCT 27.3\%), thrombocytopenia (PLT - $80 \mathrm{~K} / \mu \mathrm{l}$ ), hypoproteinemia (total protein $44.5 \mathrm{~g} / \mathrm{l}$ ). Renal failure markers were increasing (creatinine - $194 \mu \mathrm{mol} / 1$ with the normal range of $45-84$, eGFR $-32.3 \mathrm{ml} / \mathrm{min} / 1.73 \mathrm{~m}^{2}$ with the normal range of $>60$, urea $-29.51 \mathrm{mmol} / 1$ with the normal range of 2.8-8). Also AST level increased to $110 \mathrm{U} / 1$, APTT was 44.4 with the normal range of 2940 , and lipase $236 \mathrm{U} / 1$ with the normal range of 13-60. General urinalysis demonstrated proteinuria $(2 \mathrm{~g} / \mathrm{dl})$

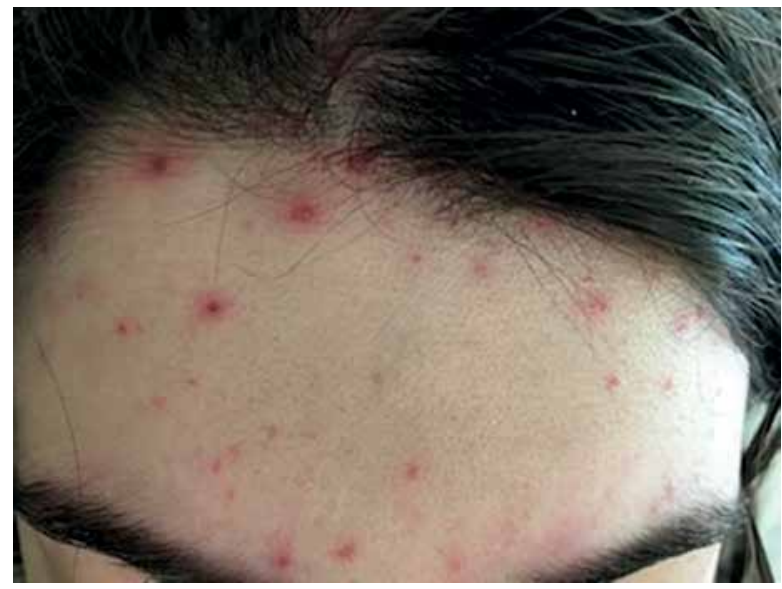

Figure I. Papular lesions with topical erosion and a tendency to exudate

Rycina I. Zmiany grudkowe z nadżerkami na szczycie i tendencją do wysięku gdzie poza wysiłkiem fizycznym była narażona na dużą ekspozycję na promieniowanie słoneczne.

Przed przyjęciem na oddział dermatologiczny kobieta była hospitalizowana na oddziale chorób zakaźnych, gdzie wykluczono infekcyjny charakter zmian. W badaniach kału wykluczono zakażenie Clostridium difficile, Campylobacter, Salmonella, Shigella oraz zakażenia rotawirusami, adenowirusami i norowirusami. Nie stwierdzono zakażenia wirusem grypy AH1N1, HIV, HBV, a także HCV. Ponadto stężenie białka C-reaktywnego (CRP) i prokalcytoniny były w granicach normy. Stężenie amylazy we krwi było podwyższone do $233 \mathrm{U} / 1$, podobnie próby wątrobowe - aminotransferaza asparaginianowa (AST) $57 \mathrm{U} / 1$. W kolejnych dniach narastało stężenie lipazy (231 U/1), mocznika (151 mg/dl) i kreatyniny (161 $\mu \mathrm{mol} / \mathrm{l})$ oraz zmniejszał się szacunkowy współczynnik filtracji kłębuszkowej (eGFR) do $36 \mathrm{ml} /$ $\mathrm{min} / 1,73 \mathrm{~m}^{2}$. Ponadto rozpoznano leukopenię, anemię, trombocytopenię i niedoczynność tarczycy (TSH - 5,16 mU/1, fT3 - 2,59 pmol/1, fT4 - 8,85 pmol/1).

$\mathrm{W}$ badaniu dermatologicznym stwierdzono obecność zmian plamisto-grudkowych zlokalizowanych na twarzy z tendencją do wysięku oraz tworzenia nadżerek na szczycie. W obrębie błony śluzowej jamy ustnej widoczne były liczne nadżerki pokryte szarożółtym, kożuchowatym nalotem (ryc. 1, 2). Czerwień wargowa była sucha, zapalnie zmieniona, z licznymi nadżerkami. Zmiany plamisto-grudkowe na udach miały znacznie mniejsze nasilenie (ryc. 3).

W badaniu przedmiotowym stwierdzono graniczne wartości ciśnienia tętniczego (RR 140/90 mm Hg), tachykardię (HR 100/min) i wzmożoną ciepłotę ciała $\left(38^{\circ} \mathrm{C}\right)$. Nad polami płucnymi szmer pęcherzykowy był symetrycznie zniesiony do wysokości kątów łopatek. Nie stwierdzono innych odchyleń.

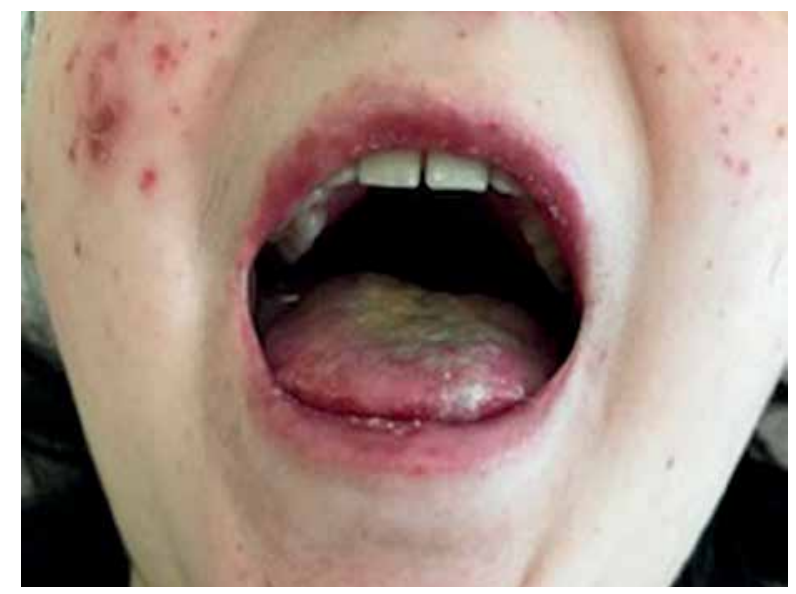

Figure 2. An abundant, grey-yellow coating on the tongue and erosions within the red zone of the lip

Rycina 2. Obfity szarożółty nalot na języku oraz nadżerki w obrębie czerwieni wargowej 


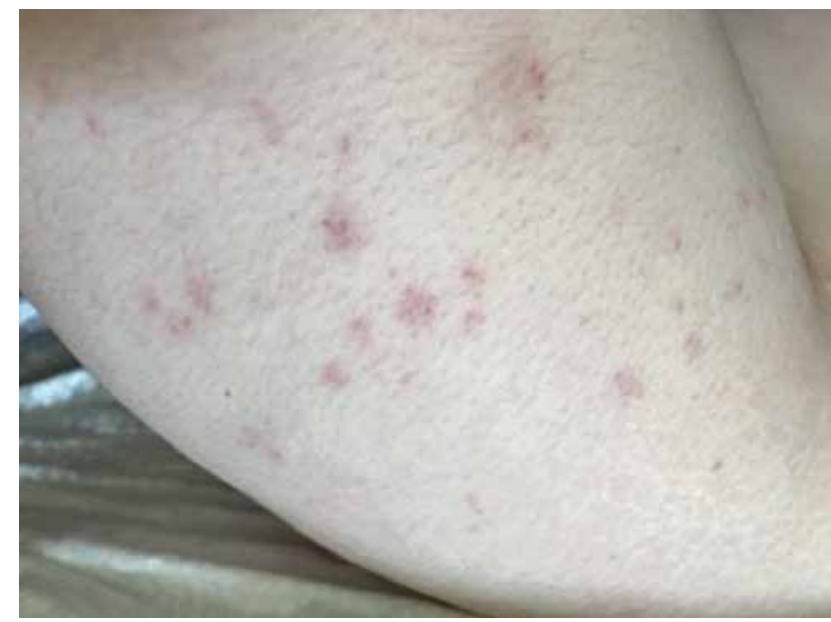

Figure 3. Maculopapular lesions on the left thigh

Rycina 3. Zmiany grudkowo-plamiste w obrębie uda lewego

with accompanying erythrocyturia with bleached RBCs. Epstein-Barr virus and varicella infections were excluded. Increased TSH levels and decreased levels of C3 and C4 components of the complement were also observed.

Computed tomography of the chest revealed fluid in bases of pleural cavities - $21 \mathrm{~mm}$ wide on the right side, and $30 \mathrm{~mm}$ on the left, and fluid in the pericardium - width of $7 \mathrm{~mm}$ on the level of the right ventricle. Additionally, a minor compression atelectasis was reported in part of basal segments of the left lung. No focal lesions nor stasis was reported.

Immunological tests demonstrated presence of anti-nuclear antbodies ANA, on HEp2 cells, titre of $>1 / 2560$, demonstrating luminescence of granular (+), nucleolar (+), homogenous (+) type and fine-granular fluorescence of the cytoplasm. The 3 - ENA profile demonstrated presence of antibodies against: SS-A (++), Ro-52 (++), dsDNA (++), nucleosomes $(+)$, histones $(++)$, DFS70 $(+++)$, and the myositis 1 profile demonstrated presence of antibodies against: $\mathrm{Ku}(+)$, PM-Scl $75(+)$, SRP (+), Ro $52(++)$. Anti-dsDNA antibodies were also assayed, using the indirect immunofluorescence using the kinetoplast of Crithidium luciliae. Their titre was 1/160, and the titre of p-ANCA antibodies was 1/160.

Systemic lupus erythematosus was diagnosed based on the clinical presentation and results of laboratory investigations. The patient met the following ACR classification criteria $[23,24]$ : presence of erosions in oral mucosa, history of hypersensitivity to sunlight, presence of wandering articular pain, serositis (of the pleura and pericardium), renal changes (proteinuria and erythrocyturia - nephritic syndrome; impaired renal function), pancytopenia, presence of ANA antibodies, presence of anti-dsDNA antibodies specific for lupus. At least 4 criteria are required for the diagnosis, but in the presented case
W badaniach laboratoryjnych w ciągu 2 dni hospitalizacji odnotowano stopniowe nasilanie się leukopenii (WBC $-2,6$ tys./ $\mu \mathrm{l}$ ), anemii (RBC $-3,34 \mathrm{mln} / \mu \mathrm{l}$; $\mathrm{Hgb}-10 \mathrm{~g} / \mathrm{dl}$; HCT 27,3\%), trombocytopenii (PLT 80 tys./ $\mu 1$ ), hipoproteinemię (białko całkowite $44,5 \mathrm{~g} / \mathrm{l})$. Pogarszały się wskaźniki niewydolności nerek (kreatynina - $194 \mu \mathrm{mol} / 1$ przy normie 45-84, eGFR - 32,3 $\mathrm{ml} / \mathrm{min} / 1,73 \mathrm{~m}^{2}$ przy normie $>60$, mocznik $29,51 \mathrm{mmol} / 1$ przy normie 2,8-8). Ponadto zwiększały się wartości AST do 110 U/1, APTT - 44,4 sekundy przy normie 29-40, oraz lipazy - $236 \mathrm{U} / 1$ przy normie 13-60. W badaniu ogólnym moczu stwierdzono białkomocz (2 g/dl) z towarzyszącym krwinkomoczem z krwinkami wyługowanymi. Wykluczono zakażenie wirusem Epsteina-Barr i ospy wietrznej. Dodatkowo stwierdzono podwyższone wartości TSH oraz zmniejszone stężenia składowych dopełniacza C3 i C4.

W tomografii komputerowej klatki piersiowej widoczny był płyn w jamach opłucnowych u podstawy - po prawej szerokości $21 \mathrm{~mm}$, po lewej $30 \mathrm{~mm}$, a także płyn w worku osierdziowym - na poziomie prawej komory szerokości $7 \mathrm{~mm}$. Dodatkowo opisywano niewielką niedodmę z ucisku części segmentów podstawnych lewego płuca. Nie opisywano zmian ogniskowych ani zastoju.

W badaniach immunologicznych obecne były przeciwciała przeciwjądrowe ANA na komórkach HEp2 w mianie $>1 / 2560$, o typie świecenia ziarnistym $(+)$, jąderkowym (+), homogennym (+) oraz drobnoziarnistej fluorescencji cytoplazmy. W profilu 3 - ENA stwierdzono przeciwciała przeciwko: SS-A (++), Ro-52 (++), dsDNA (++), nukleosomom $(+)$, histonom $(++)$, DFS70 $(+++)$, natomiast w profilu myositis 1 przeciwciała przeciwko: $\mathrm{Ku}(+)$, PM-Scl 75 $(+)$, SRP (+), Ro $52(++)$. Oznaczono także przeciwciała anty-dsDNA metodą immunofluorescencji pośredniej na wiciowcu Crithidium luciliae, które były obecne 
8 of 11 ACR criteria were met. Analysis of SLICC classification criteria [25] the following were met: acute dermatological lesions in form of generalised maculopapular rash, ulceration of the oral cavity, pain and morning rigidity of joints persisting for at least 30 minutes, serositis, occupation of kidneys, anaemia, leukopenia, thrombocytopenia, presence of ANA antibodies, presence of anti-dsDNA antibodies, reduced titre of the complement C3 and C4. So, 11 of 17 classification criteria were met in the presented case.

The patient was intensively treated. A balance of fluid was recommended. A pulse with $500 \mathrm{mg}$ of methylprednisolone was introduced, local glucocorticosteroids were introduced and antimycotic medication was applied for the oral mucosa.

Considering signs of acute kidney injury the patient was transferred to the Nephrology ward, where infusions with methylprednisolone were continued. Because of the patient's young age, mycophenolate mofetil (MMF) was initially introduced. In face of fulminating course of the disease, with acute kidney injury and developing multi-organ failure, a decision was made to administer a cycle of plasmaphereses. Total 10 procedures were performed with fresh-frozen plasma (FFP) and albumins. Considering progressive anaemia, the patient received transfusions with leukocyte-depleted irradiated packed red blood cells - total amount of 5 units. After 1 week, in face of persistent signs of activity of the disease, MMF was discontinued and infusions with cyclofosfamide (CYF) were introduced under protection of AntiUromitexan, according to the EURO-LUPUS scheme [26]. Infusions were continued in 2-week intervals, and methyloprednisolon was administered p.o. (the dose corresponding to $0.5 \mathrm{mg} / \mathrm{kg} \mathrm{b.w}$. of prednisone), along with chloroquine under protection of cotrimoxazole. Hypotensive medication, including loop diuretics (furosemide), were used to treat high arterial blood pressure. Considering signs of acute kidney injury with oligouria, the patient required kidney-replacement therapy. Total 5 procedures of haemodialysis were performed. A gradual improvement of the patient's clinical condition was observed over subsequent days - disappearance of skin changes and erosions in the oral cavity, return of diuresis and reduction of fluid retention symptoms. Renal function parameters are improved, along with normalisation of hepatic and pancreatic enzymes, improvement of blood cell count parameters and reduction of exudate confirmed by imaging diagnostics. After administration of the $4^{\text {th }}$ pulse of CYF the dose of methylprednisolone was downtitrated. After conclusion of CYF infusions, Azathioprin at the dose of $75 \mathrm{mg}$ / day was introduced, with continued administration of methylprednisolone and chloroquine. Laboratory parameters returned w mianie $1 / 160$, oraz stwierdzono przeciwciała przeciwko p-ANCA w mianie 1/160.

Na podstawie obrazu klinicznego i wyników badań laboratoryjnych rozpoznano SLE. Chora spełniła następujące kryteria klasyfikacyjne wg ACR [23, 24]: obecność zmian nadżerkowych w obrębie błony śluzowej jamy ustnej, nadwrażliwość na słonce w wywiadzie, obecność wędrujących bólów stawowych, zapalenie błon surowiczych (opłucnej i osierdzia), zmiany nerkowe (białkomocz, krwinkomocz - zespół nefrytyczny; pogorszona czynność nerek), pancytopenia, obecność przeciwciał przeciwjądrowych ANA, obecność specyficznych dla tocznia przeciwciał anty-dsDNA. Do rozpoznania choroby niezbędne są co najmniej 4 kryteria, natomiast u przedstawianej pacjentki stwierdzono 8 spośród 11 kryteriów ACR. Analizując kryteria klasyfikacyjne SLICC [25], stwierdzono następujące: zmiany skórne o charakterze ostrym w postaci uogólnionej osutki plamisto-grudkowej, owrzodzenia jamy ustnej, bóle i sztywność poranną stawów utrzymującą się ponad 30 minut, zapalenie błon surowiczych, zajęcie nerek, niedokrwistość, leukopenię, trombocytopenię, obecność przeciwciał przeciwjądrowych ANA, obecność przeciwciał anty-dsDNA, obniżone miano dopełniacza C3 i C4. Potwierdzono 11 spośród 17 możliwych kryteriów klasyfikacyjnych.

Pacjentkę poddano intensywnej opiece medycznej, zalecono bilans płynów, włączono puls z metyloprednizolonu w dawce $500 \mathrm{mg}$, miejscowe leki glikokortykosteroidowe, a na błonę śluzową jamy ustnej również leki przeciwgrzybicze.

Ze względu na objawy ostrego uszkodzenia nerek pacjentka została przeniesiona na oddział nefrologii, gdzie kontynuowano wlewy z metyloprednizolonu. Z uwagi na młody wiek kobiety początkowo włączono mykofenolan mofetylu (MMF). Z powodu piorunującego przebiegu choroby z ostrym uszkodzeniem nerek i rozwijającą się niewydolnością wielonarządową zdecydowano o wykonaniu cyklu plazmaferez (PF) - łącznie 10 zabiegów z użyciem świeżo mrożonego osocza (FFP) oraz albumin. W związku $\mathrm{z}$ anemizacją przetaczano napromieniowany, ubogoleukocytarny koncentrat krwinek czerwonych (NUKKCz) - łącznie 5 j. Po tygodniu, ze względu na utrzymujące się cechy aktywności choroby, odstawiono MMF i rozpoczęto wlewy z cyklofosfamidu (CYF) $\mathrm{w}$ osłonie z AntiUromitexanu zgodnie ze schematem EURO-LUPUS [26], które kontynuowano w odstępach 2-tygodniowych łącznie z doustnym preparatem metyloprednizolonu (dawka odpowiadająca $0,5 \mathrm{mg} / \mathrm{kg} / \mathrm{m}$.c. prednizonu) oraz chlorochiny w osłonie kotrimoksazolu. W związku z wysokim ciśnieniem tętniczym stosowano leki hipotensyjne, w tym diuretyki pętlowe (furosemid). Chora wymagała czasowego leczenia nerkozastępczego ze 
back to normal after 4 months of treatment. At present the patient requires no diuretics nor hypotensive drugs.

\section{DISCUSSION}

Classification criteria are helpful in making the diagnosis of SLE. Those criteria were repeatedly modified with acquisition of experience. At present ACR criteria are the most commonly used [23, 24], and since 2012 also the SLICC classification [25], considered to be more sensitive. Systemic lupus erythematosus symptoms assessed according to those criteria usually develop gradually. A rapid development of lupus and dysfunction of multiple organs, as it was in the presented case, are rarely observed [27].

Dermatological lesions occurring in course of SLE are variable, but - importantly - their form and dynamics are sometimes correlated with activity of the pathological process. Acute changes (ACLE - acute cutaneous lupus erythematosus) may be localised (butterfly-type facial erythema) or generalised, as in the presented case. The latter ones are far less common. Similarly to the presented case, generalised acute eruptions are manifested as maculopapular rash resembling drug-induced lesions or lesions associated with measles. Eruptions are symmetrically distributed and occupy the face, the trunk and extremities. They are often accompanied by vascular lesions, and nailfolds are erythematous, with dilation of blood vessels and hypertrophy of cuticle [27]. Those lesions are significantly photosensitive and do not last long. Usually they reside in days or weeks after introduction of treatment. They do not demonstrate a tendency for atrophy and cicatrizartion. More commonly they accompany organ dysfunction - mostly renal failure, and sometimes they are a "dermatological manifestation" of acute and life-threatening course of disease.

Fever is commonly present in SLE, and occurs in $36 \%$ to $86 \%$ of patients [28]. According to Canadian anuthors, confirmed by our observation, cases of increased body temperature are usually noted at early stage of disease [29]. Fever is considered a symptom of SLE after exclusion of its other possible causes [28]. For that reason, the parameter - although common is not included in classification criteria as not specific enough. Differential diagnosis has to consider the level of CRP and procalcitonin. Levels of those proteins are high in infectious diseases, and low in the active phase of lupus [30]. In the presented case both parameters remained within their normal ranges.

A significant part of SLE patients (approx. 70\%) present clinical symptoms or laboratory signs of kidney occupation. Renal problems may be the first manifestation of disease, but extremely rarely. In $50 \%$ of względu na cechy ostrego uszkodzenia nerek przebiegającego z oligurią; łącznie wykonano 5 zabiegów hemodializy. W kolejnych dniach leczenia obserwowano stopniową poprawę stanu klinicznego - ustąpienie zmian skórnych, nadżerek w jamie ustnej, powrót diurezy, ustępowanie objawów retencji płynów. Stwierdzono także poprawę parametrów czynności nerek, normalizację enzymów wątrobowych i trzustkowych, poprawę parametrów morfologii krwi obwodowej oraz zmniejszenie wysięków w badaniach obrazowych. Po podaniu dożylnie pulsu z CYF stopniowo zmniejszano dawkę metyloprednizolonu. Po zakończeniu wlewów CYF włączono jako terapię podtrzymującą azatioprynę w dawce $75 \mathrm{mg} /$ dobę $\mathrm{z}$ kontynuacją metyloprednizolonu oraz chlorochiny. Po 4 miesiącach leczenia stwierdzono normalizację parametrów laboratoryjnych. Obecnie pacjentka nie wymaga leków moczopędnych ani hipotensyjnych.

\section{OMÓWIENIE}

W rozpoznaniu SLE pomocne są kryteria klasyfikacyjne, które wraz ze zdobywaniem kolejnych doświadczeń były wielokrotnie modyfikowane. Obecnie powszechnie stosowane są kryteria ACR [23, 24], a od 2012 roku również SLICC [25], które uznawane są za bardziej czułe. Oceniane w powyższych systemach klasyfikacyjnych objawy SLE zwykle rozwijają się stopniowo, rzadko obserwuje się tak dynamiczny rozwój tocznia i jednoczesne pojawienie się dysfunkcji wielu narządów jak w prezentowanym przypadku [27].

W przebiegu SLE zmiany skórne są różnorodne, ale co istotne, niekiedy ich postać i dynamika korelują $\mathrm{z}$ aktywnością procesu chorobowego. Zmiany o ostrym charakterze (ACLE - acute cutaneous lupus erythematosus) mogą być zlokalizowane (rumień na twarzy o typie motyla) lub uogólnione jak w przypadku naszej pacjentki. Te drugie obserwowane są znacznie rzadziej. Podobnie jak w przedstawionym przypadku uogólnione wykwity o ostrym charakterze i przebiegu objawiają się jako osutka plamisto-grudkowa przypominająca zmiany polekowe lub zmiany w przebiegu odry. Wykwity zlokalizowane są symetrycznie i zajmują twarz, tułów i kończyny, często towarzyszą im zmiany naczyniowe, a w obrębie wałów paznokciowych widoczny jest rumien, poszerzenie naczyń i przerost oskórka [27]. Zmiany o tym charakterze cechują się znaczną fotowrażliwością i nie utrzymują się długo. Zwykle ustępują po kilku dniach lub tygodniach od włączenia terapii. Nie mają tendencji do zaniku i bliznowacenia. Częściej towarzyszą dysfunkcji narządowej, głównie niewydolności nerek, niekiedy są "skórną manifestacją" ostrego, zagrażającego życiu przebiegu choroby.

Gorączka jest częstym objawem występującym w SLE i dotyczy 36-86\% pacjentów [28]. Według na- 
patients, renal symptoms develop within first 3 years of the diagnosis. Kidney injury caused by the immunological process is associated with a very unfavourable prognosis [31-33]. The risk of death is significantly higher for SLE patients compared to the general population. It is particularly high in those individuals, in whom intensive organ changes developed at younger age [34, 35].

Presence of DFS70 antibodies that appeared at the same time as lupus-specific anti-dsDNA antibodies, requires a separate discussion. Although their presence rises controversies, it is commonly agreed that if they are present alone, the autoimmune background of a disease may be usually excluded [36]. But in case of their simultaneous presence with specific antibodies - as it was in the presented case - they do not negate the diagnosis of SLE.

Treatment of SLE is aimed at as fast control over the active phase of the disease, as possible, and at prevention of recurrence and organ injuries. There is no uniform therapeutic procedure, and a tendency to personalised treatment, directed to complete o partial remission of symptoms and organ manifestations (treat to target) seems to dominate lately [27]. The broad therapeutic spectrum involves antimalaria drugs, glucocorticosteroids, cytotoxic and immunosuppresive drugs (CYF, MMF, azathioprin, cyclosporine, methotrexate). The application of PF, intravenous infusions with immunoglobulins, or biological drugs is sometimes effective [37].

Lupus nephritis (LN) is a life-threatening organ dysfunction requiring intensive immunosuppresive treatment [38]. In 10-20\% of LN a terminal kidney failure develops [39]. In the presented case it was necessary to introduce the combination of CYF and glucocorticosteroids, and a decision was made to perform a cycle of PF because of a rapid development of multi-organ failure. Haemodialysis was used as the symptomatic treatment. Cyclofosfamide still remains a gold standard in treatment of severe, life-threatening lupus with organ occupation (mainly kidneys and the central nervous system). Cyclofosfamide is more effective in the treatment of lupus nephropathy than steroid therapy alone [40,41]. Cyclofosfamide pharmacotherapy combined with steroid therapy is effective in induction of remission in nearly $80 \%$ of patients [42, 43]. Also MMF has been lately used for induction of remission and for supportive therapy. Efficacy of the agent is comparable to that of CYF and azathioprin [44, 45]. In case of development of acute kidney injury in course of SLE, and if clinical and biochemical indications are present, the use of dialysis may be necessary. Dialysis is continued until improvement of renal function. In case of irreversible kidney injury, kidney-replacement therapy is continued until the patient's death. In that situation, szych obserwacji, a także na podstawie pracy autorów z Kanady przypadki podwyższonej ciepłoty ciała stwierdza się zazwyczaj we wczesnym stadium choroby [29]. Obecność podwyższonej ciepłoty ciała uznaje się za objaw SLE po wykluczeniu innych przyczyn [28]. Dlatego parametr ten - częsty, ale mało swoisty nie znalazł się w kryteriach klasyfikacyjnych. W rozpoznaniu różnicowym należy uwzględnić stężenia CRP i prokalcytoniny, które są duże w przebiegu chorób infekcyjnych, a małe w przebiegu aktywnej fazy tocznia [30]. W prezentowanym przypadku oba te parametry mieściły się $\mathrm{w}$ granicach normy.

U znacznej części chorych na SLE (ok. 70\%) występują objawy kliniczne lub laboratoryjne parametry zajęcia nerek. Może to być pierwsza manifestacja choroby, jednak taką sytuację stwierdza się niezwykle rzadko. U 50\% pacjentów objawy nerkowe rozwijają się w czasie pierwszych 3 lat od ustalenia rozpoznania. Uszkodzenie nerek spowodowane procesem immunologicznym wiąże się z bardzo poważnym rokowaniem [31-33]. Ryzyko zgonu pacjentów z SLE jest istotnie wyższe $\mathrm{w}$ porównaniu z populacją ogólną. Jest ono szczególnie wysokie u osób, u których nasilone zmiany narządowe pojawiły się w młodszym wieku [34, 35].

Odrębnego omówienia wymaga obecność przeciwciał DFS70, które stwierdzono równolegle ze swoistymi dla tocznia przeciwciałami skierowanymi przeciwko dsDNA. Ich obecność wzbudza szereg kontrowersji, jednak powszechna jest teza, że jeśli występują jako jedyne, to zwykle można wykluczyć autoimmunologiczne tło choroby [36]. Ich jednoczesna obecność z przeciwciałami swoistymi, jak w przedstawionym przypadku, nie wyklucza diagnozy SLE.

Leczenie SLE ma na celu jak najszybsze opanowanie aktywnej fazy choroby, zapobieganie nawrotom oraz uszkodzeniom narządowym. Nie ma jednolitego postępowania terapeutycznego, a w ostatnich latach przeważa tendencja do leczenia spersonalizowanego, ukierunkowanego na osiągnięcie całkowitej lub częściowej remisji objawów i manifestacji narządowych (treat to target) [27]. W szerokim spektrum terapeutycznym pozostają leki przeciwmalaryczne, glikokortykosteroidy, leki cytotoksyczne i immunosupresyjne (CYF, MMF, azatiopryna, cyklosporyna, metotreksat). W niektórych przypadkach skuteczne jest zastosowanie PF, wlewów dożylnych immunoglobulin czy leków biologicznych [37].

Toczniowe zapalenie nerek (lupus nephritis - LN) należy do zagrażających życiu dysfunkcji narządowych i wymaga intensywnego leczenia immunosupresyjnego [38]. U 10-20\% pacjentów z LN rozwija się schyłkowa niewydolność nerek [39]. W przedstawionym przypadku konieczne było połączenie leczenia CYF z glikokortykosteroidami oraz ze względu na rozwijającą się gwałtownie niewydolność wielona- 
transplantation of the injured organ is the best solution, and the immunosuppresive treatment is administered simultaneously with the SLE therapeutic regimen [46]. "Silencing" of clinical and serological markers of activity of the disease is often observed during dialysis therapy [47]. Despite improvement of the overall survival of patients with systemic lupus, for $10-25 \%$ of affected patients there is a risk of death in 10 years [48]. PF may be considered in case of severe lupus with organ occupation. PF is a procedure consisting in separation of plasma, and its elimination along with substances of high molecular weight. Blood cells are returned to circulation dissolved in substitution fluid. The procedure removes immunological complexes suspended in plasma, antibodies and elements of the complement. The method is well tolerated by patients, and the best effects are achieved in patients with severe SLE and high levels of circulating antibodies [49].

Systemic lupus erythematosus is a disease of a variable clinical presentation. Its acute onset often imitates an infection. Exposure to UV radiation, and sometimes also physical exercise, are known and the most common triggers of the disease, provoking development or intensification of dermatological and organ-associated changes. The presented case indicates that symptoms of the disease are not always typical, and that the first manifestation of the disease may be severe and life-threatening.

\section{CONFLICT OF INTEREST}

The authors declare no conflict of interest. rządową zdecydowano o wykonaniu cyklu PF. Jako leczenie objawowe stosowano hemodializoterapię. Cyklofosfamid jest nadal złotym standardem w leczeniu ciężkiego, zagrażającego życiu tocznia z zajęciem narządów, zwłaszcza nerek i ośrodkowego układu nerwowego. Stosowanie CYF jest bardziej efektywne w leczeniu nefropatii toczniowej niż sama steroidoterapia $[40,41]$. Farmakoterapia CYF w połączeniu ze steroidoterapią jest skuteczna $\mathrm{w}$ indukcji remisji u prawie $80 \%$ chorych $[42,43]$. Ostatnio do indukcji remisji oraz leczenia podtrzymującego wykorzystuje się również MMF, którego skuteczność jest porównywalna z CYF oraz azatiopryną [44, 45]. W przypadku wystąpienia ostrego uszkodzenia nerek w przebiegu SLE oraz obecności wskazań klinicznych i biochemicznych może być konieczna dializoterapia, którą kontynuuje się do czasu poprawy czynności nerek. $W$ razie nieodwracalnego uszkodzenia nerek leczenie nerkozastępcze prowadzone jest do końca życia. W takiej sytuacji najlepszym rozwiązaniem jest przeszczepienie niewydolnego narządu, a stosowane leczenie immunosupresyjne jednocześnie jest leczeniem SLE [46]. Podczas dializoterapii obserwuje się często "wyciszenie" klinicznych i serologicznych wskaźników aktywności choroby [47]. Pomimo poprawy ogólnego czasu przeżycia pacjentów z toczniem układowym, u 10-25\% osób z tej grupy istnieje prawdopodobieństwo zgonu w ciągu 10 lat [48]. W ciężkim przebiegu tocznia $z$ zajęciem narządów można rozważyć wykonanie plazmaferezy. Plazmafereza to zabieg polegający na separacji osocza, a następnie jego eliminacji wraz z substancjami o dużej masie cząsteczkowej. Do krwiobiegu wraz z płynem substytucyjnym zwracane sa elementy morfotyczne krwi. Podczas tych zabiegów usuwa się wraz z osoczem zawieszone w nim kompleksy immunologiczne, krążące przeciwciała i składniki dopełniacza. Jest to metoda dobrze tolerowana przez pacjentów, a najlepsze efekty osiąga się u chorych $\mathrm{z}$ ciężką postacią SLE, z wysokimi poziomami krążących przeciwciał [49].

Toczeń rumieniowaty układowy jest chorobą o różnorodnym obrazie klinicznym, której ostry początek często imituje infekcję. Ekspozycja na promieniowanie ultrafioletowe, a czasem również wysiłek fizyczny należą do uznanych i najczęstszych czynników prowokujących wystąpienie lub nasilenie zmian skórnych oraz narządowych. Prezentowany przypadek wskazuje, że objawy nie zawsze mają typowy obraz, a pierwsza manifestacja choroby może mieć ciężki, zagrażający zdrowiu i życiu przebieg.

\section{KONFLIKT INTERESÓW}

Autorzy nie zgłaszają konfliktu interesów. 


\section{References}

\section{Piśmiennictwo}

1. Tsokos G.C., Lo M.S., Costa Reis P., Sullivan K.E: New insights into the immunopathogenesis of systemic lupus erythematosus. Nat Rev Rheumatol 2016, 12, 716-730.

2. Petri M., Orbai A.M., Alarcón G.S., Gordon C., Merrill J.T., Fortin P.R., et al.: Derivation and validation of the Systemic Lupus International Collaborating Clinics classification criteria for systemic lupus erythematosus. Arthritis Rheum 2012, 64, 2677-2686

3. Jabłońska S., Majewski S.: Choroby tkanki łącznej. [In:] Choroby skóry i choroby przenoszone drogą płciową. S. Jabłońska, S. Majewski (red.). PZWL, Warszawa, 2005, 261-272.

4. Tsokos G.C.: Systemic lupus erythematosus. N Engl J Med 2011, 365, 2110-2121.

5. Zandman-Goddard G., Solomon M., Rosman Z., Peeva E., Shoenfeld Y.: Environment and lupus-related diseases. Lupus 2012, 21, 241-250.

6. Rigante D., Mazzoni M.B., Esposito S.: The cryptic interplay between systemic lupus erythematosus and infections. Autoimmun Rev 2014, 13, 96-102.

7. Barzilai O., Ram M., Shoenfeld Y.: Viral infection can induce the production of autoantibodies. Curr Opin Rheumatol 2007, 19, 636-643.

8. Sebastiani G.D., Galeazzi M.: Infection genetics relationship in systemic lupus erythematosus. Lupus 2009, 18, 1169-1175.

9. Lisnevskaia L., Murphy G., Isenberg D.: Systemic lupus erythematosus. Lancet 2014, 384, 1878-1888.

10. Zandman-Goddard G., Solomon M., Rosman Z., Peeva E., Shoenfeld Y.: Environment and lupus-related diseases. Lupus $2012,21,241-250$

11. Kuhn A., Wenzel J., Weyd H.: Photosensitivity, apoptosis, and cytokines in the pathogenesis of lupus erythematosus: a critical review. Clin Rev Allergy Immunol 2014, 47, 148-162.

12. Yu C., Chang C., Zhang J.: Immunologic and genetic considerations of cutaneous lupus erythematosus: a comprehensive review. J Autoimmun 2013, 41, 34-45.

13. James J.A., Neas B.R., Moser K.L., Hall T., Bruner G.R., Sestak A.L., et al.: Systemic lupus erythematosus in adults is associated with previous Epstein-Barr virus exposure. Arthritis Rheum 2001, 44, 1122-1126.

14. Tugnet N., Rylance P., Roden D., Trela M., Nelson P.: Human endogenous retroviruses (HERVs) and autoimmune rheumatic disease: is there a link? Open Rheumatol J 2013, 7, 13-21.

15. Pullmann R. Jr., Bonilla E., Phillips P.E., Middleton F.A., Perl A.: Haplotypes of the HRES-1 endogenous retrovirus are associated with development and disease manifestations of systemic lupus erythematosus. Arthritis Rheum 2008, 58, 532-540.

16. Perl A., Fernandez D., Telarico T., Phillips P.E.: Endogenous retroviral pathogenesis in lupus. Curr Opin Rheumatol 2010, $22,483-492$.

17. Graham R.R., Ortmann W., Rodine P., Espe K., Langefeld C., Lange E., et al.: Specific combinations of HLA-DR2 and DR3 class II haplotypes contribute graded risk for disease susceptibility and autoantibodies in human SLE. Eur J Hum Genet 2007, $15,823-830$.

18. Moser K.L., Kelly J.A., Lessard C.J., Harley J.B.: Recent insights into the genetic basis of systemic lupus erythematosus. Genes Immun 2009, 10, 373-379.

19. Tsokos G.C., Kammer G.M.: Molecular aberrations in human systemic lupus erythematosus. Mol Med Today 2000, 6, 418-24.

20. Shelly S., Boaz M., Orbach H.: Prolactin and autoimmunity. Autoimmun Rev 2012, 11, A465-A470.

21. Cunningham M., Gilkeson G.: Estrogen receptors in immunity and autoimmunity. Clin Rev Allergy Immunol 2011, 40, 66-73.

22. Chan K.L., Mok C.C.: Development of systemic lupus erythematosus in a male-to-female transsexual: the role of sex hormones revisited. Lupus 2013, 22, 1399-1402.

23. Tan E.M., Cohen A.S., Fries J.F., Masi A.T., McShane D.J., Rothfield N.F., et al.: The 1982 revised criteria for the classification of systemic lupus erythematosus. Arthritis Rheum 1982, 25, 1271-1277.

24. Hochberg M.C.: Updating the American College of Rheumatology revised criteria for the classification of systemic lupus erythematosus. Arthritis Rheum 1997, 40, 1725.

25. Petri M., Orbai A.M., Alarcón G.S., Gordon C., Merrill J.T., Fortin P.R., et al.: Derivation and validation of the Systemic Lupus International Collaborating Clinics classification criteria for systemic lupus erythematosus. Arthritis Rheum 2012, 64, 2677-2686

26. Houssiau F.A., Vasconcelos C., D'Cruz D., Sebastiani G.D., de Ramon Garrido E., Danieli M.G., et al.: The 10-year follow-up data of the Euro-Lupus Nephritis Trial comparing low-dose and high-dose intravenous cyclophosphamide. Ann Rheum Dis 2010, 69, 61-64.

27. Woźniacka A., Sysa-Jędrzejowska A., Reich A., Szepietowski J., Błaszczyk M., Lis-Święty A., et al.: Cutaneous lupus erythematosus. Diagnostic and therapeutic recommendations of the Polish Dermatological Society. Dermatol Rev 2018, 105, 244-263.

28. Timlin H., Syed A., Haque U., Adler B., law G., Machireddy K., et al.: Fevers in Adult Lupus Patients. Muacevic A, Adler JR (eds.). Cureus 2018, 10, 2098.

29. Stahl N., Klippel J., Decker J.: Fever in systemic lupus erythematosus. Am J Med 1979, 67, 935-940.

30. Rovin B., Tang Y., Sun J., Nagaraja H.N., Hackshaw K.V., Gray L., et al.: Clinical significance of fever in the systemic lupus erythematosus patient receiving steroid therapy. Kidney Int 2005, 68, 747-759.

31. Komolafe O.O.: Rapidly progressive glomerulonephritis: a wild card manifestation of lupus nephritis. Saudi J Kidney Dis Transpl 2018, 29, 443-451.

32. Kwok S.K., Tsokos G.C.: New insights into the role of renal resident cells in the pathogenesis of lupus nephritis. Korean J Internal Med 2018, 33, 284-289. 
33. Feldman C.H., Hiraki L.T., Liu J., Fischer M.A., Solomon D.H., Alarcón G.S., et al.: Epidemiology and sociodemographics of systemic lupus erythematosus and lupus nephritis among US adults with medicaid coverage, 2000-2004. Arthritis Rheum 2013, 65, 753-763.

34. O'Neill S., Cervera R.: Systemic lupus erythematosus. Best Pract Res Clin Rheumatol 2010, 24, 841-855.

35. Urowitz M.B., Gladman D.D., Tom B.D., Ibanez D., Farewell V.T.: Changing patterns in mortality and disease outcomes for patients with systemic lupus erythematosus. J Rheumatol 2008, 35, 2152-2158.

36. Fabris M., Zago S., Tosolini R., Melli P., Bizzaro N., Tonutti E.: Anti-DFS70 antibodies: a useful biomarker in pediatric case with suspected autoimmune disease. Pediatrics 2014, 134, 1706-1708.

37. Majdan M.: Systemic lupus erythematosus. Reumatologia 2016, supl. 1, 26-35.

38. Appel G.B., Jayne D.: Lupus nephritis. In: Comprehensive Clinical Nephrology. J. Floege, R.J. Johnson, J. Feehally (eds). Elsevier Saunders, St Louis, Missouri 2010, 308-321.

39. Berden J.H.M.: Lupus nephritis. Kidney Int 1997, 52, 538-558.

40. Petri M.: Cyclophosphamide: new approaches for systemic lupus erythematosus. Lupus 2004, 13, 366-371.

41. Boumpas D.T., Austin III H.A., Vaughn E.M., Klippel J.H., Steinberg A.D., Yarboro C.H., et al.: Controlled trial of pulse methylprednisoloneversus two regimens of pulse cyclophosphamide in severe lupus nephritis. Lancet 1992, 340, 741-745.

42. Houssiau F.A.: Therapy of lupus nephritis: lessons learned from clinical research and daily care of patients. Arthritis Res Ther 2012, 14, 202

43. Popescu A., Kao A.H.: Neuropsychiatric systemic lupus erythematosus. Curr Neuropharmacol 2011, 9, $449-457$.

44. Rovin B.H., Parikh S.V., Hebert L.A., Chan T.M., Mok C.C., Ginzler E.M., et al.: Lupus nephritis: induction therapy in severe lupus nephritis - should MMF be considered the drug of choice? Clin J Am Soc Nephrol 2013, 8, $147-153$.

45. Dooley M.A., Jayne D., Ginzler E.M., Isenberg D., Olsen N.J., Wofsy D., et al.: Mycophenolate versus azathioprine as maintenance therapy for lupus nephritis. N Engl J Med 2011, 365, 1886-1895.

46. Zalecenia dotyczące leczenia immunosupresyjnego po przeszczepieniu narządów unaczynionych. M. Durlik, K. Zieniewicz (eds). Polskie Towarzystwo Transplantacyjne, Warsaw 2016.

47. Cheigh J.S., Kim H., Stenzel K.H., Chami J., Sullivan J.F.: Systemic lupus erythematosus in patients with endstage renal disease: long-term follow-up on the prognosis of patients and the evolution of lupus activity. Am J Kidney Dis 1990, 16, $189-195$.

48. Ward M.M., Pyun E., Studenski S.: Mortality risks associated with specific clinical manifestations of systemic lupus erythematosus. Arch Intern Med 1996, 156, 1337-1344.

49. Jones J.V.: Plasmapheresis in SLE. Clin Rheum Dis 1982, 8, 243-260.

Received: 24.09 .2018

Accepted: 6.02 .2019

Otrzymano: $24.09 .2018 \mathrm{r}$

Zaakceptowano: $6.02 .2019 \mathrm{r}$.

How to cite this article

Skręta-Śliwińska M., Woźniacka A., Kurnatowska I., Goździk M., Żebrowska A.: Rapid onset of systemic lupus erythematosus with rarely observed dermatological lesions. Dermatol Rev/Przeg1 Dermatol 2019, 106, 291-301. DOI: https://doi.org/10.5114/ dr.2019.86911. 